\title{
EFFECTS OF DIFFERENT OXYGEN CONCENTRATIONS ON THE DEVELOPMENT OF RAT EMBRYOS IN CULTURE
}

\author{
D. A. T. NEW AND P. T, COPPOLA \\ Marshall Laboratory, Department of Physiology, University of Cambridge
}

(Received 21st November 1968)

\begin{abstract}
Summary. Rat embryos explanted with their membranes at $9 \frac{1}{2}, 10 \frac{1}{2}$, and $11 \frac{1}{2}$ days' gestation have been grown in homologous serum under different conditions of oxygenation. In circulating serum, maximum growth of the younger embryos was obtained in $5 \% \mathrm{CO}_{2}$ in air and of the older embryos in $5 \% \mathrm{CO}_{2}$ in $95 \% \mathrm{O}_{2}$. In watch glass cultures, the younger embryos developed well in $5 \% \mathrm{CO}_{2}$ in 60 to $95 \% \mathrm{O}_{2}$, but growth of the older embryos could only be obtained in hyperbaric oxygen. The yolk sac of the older embryos continued to expand normally under oxygen conditions which were inadequate for growth of the embryos, but the heart and blood circulation functioned best under conditions which were optimal for embryonic growth. Although the proportion of $\mathbf{O}_{2}$ required in the gas phase varied greatly with the type of culture and the stage of development of the embryo, the results could be explained on the assumption that embryonic tissues at all stages require an $\mathrm{O}_{2}$ pressure similar to that provided by blood in equilibrium with air.
\end{abstract}

\section{INTRODUCTION}

Explanted rat embryos of post-implantation stages can be grown in homologous serum, either in watch glass cultures (New, 1966b) or in circulating serum (New, 1967). These methods are of value in studying mammalian embryo physiology and in investigating the causes of embryonic malformations (e.g. Turbow, 1966). Berry (1968) has recently examined the growth rates of rat embryos in culture, and Givelber \& Di Paolo (1968) have successfully used the circulator method for growing post-implantation hamster embryos.

A critical requirement of embryos in culture is a carefully regulated $\mathrm{O}_{2}$ supply. This can be varied in three ways: (1) by altering the proportion of $\mathrm{O}_{2}$ in the gas phase of the culture vessel, (2) by increasing the pressure of the gas phase-hyperbaric oxygen, (3) by altering the rate of flow of oxygenated medium round the embryo. Previous work has suggested that there might be an optimum $\mathrm{O}_{2}$ level for each stage of embryonic development. This paper describes the effects of variations of $\mathrm{O}_{2}$ supply on rat embryos explanted at different stages. 


\section{MATERIALS AND METHODS}

Embryos were obtained from the Hooded and Wistar strains of rats, and were explanted with their embryonic membranes by a method similar to that described previously (New, 1966a, 1970). Each conceptus was dissected free of the surrounding decidua in Tyrode saline and, before the conceptus was placed in the culture vessel, the Reichert membrane was torn open.

The culture medium used throughout was homologous serum containing 50 $\mu \mathrm{g} / \mathrm{ml}$ streptomycin. The serum was obtained from the dorsal aorta of rats anaesthetized with ether and it was stored for periods of up to I week at 1 to $4^{\circ} \mathrm{C}$ or for longer periods at $-10^{\circ} \mathrm{C}$.

Some of the embryos were grown in watch glasses of serum, housed in Petri dishes lined with wet gauze (New, 1966b) as in the standard method for organ culture. Others were grown in small tubular chambers through which serum was circulated. Except where stated otherwise, these chambers were square in cross section, $7 \times 7 \mathrm{~mm}$ internal.

The apparatus for maintaining circulation of the serum has been described previously (New, 1967). The only modification introduced was an improvement in the method of anchoring the embryos within the embryo chamber. Previously the embryos were attached by means of the opened Reichert membrane to a strip of untreated rayon fabric stuck to a piece of glass coverslip with a few drops of acetone. It has been found more reliable to soak the rayon before use in thick collagen solution and then to allow it to dry on to the coverslip. Not only does this improve the adhesion between rayon and coverslip, but when the Reichert membrane of the explant is pressed against the treated rayon it also attaches more firmly.

The gas in which the embryos were grown always contained $5 \% \mathrm{CO}_{2}$ although the proportion of $\mathrm{O}_{2}$ was varied. The watch glass cultures were incubated in sealed chambers containing the required gas mixture. The serum in the 'circulators' was oxygenated by bubbling the gas through it.

All cultures were terminated after 40 to $50 \mathrm{hr}$ incubation. The main criteria used in estimating the development and duration of survival of the embryos in culture were the rate of heart beat, persistence of the blood circulation, and the final number of somites and protein content. Protein determinations were always made on the embryos alone after dissecting them free of the embryonic membranes; the embryos were digested in $\mathrm{NaOH}$ and the protein was estimated by comparison with standard solutions of bovine plasma albumin, using the colorimetric method of Lowry, Rosebrough, Farr \& Randall (1951).

\section{RESULTS}

Embryos explanted at $9 \frac{1}{2}$ days (primitive streak to head-fold)

Table 1 summarizes the results from embryos explanted into circulators at $9 \frac{1}{2}$ days, and grown in serum equilibrated with three different $\mathrm{O}_{2}$ concentrations and circulated at various rates of flow. Each treatment was given to a group of four to eight embryos, care being taken that the embryos in the different groups were comparable as regards stage of development at the time of 
explantation. Where the $\mathrm{O}_{2}$ concentration or rate of flow was altered during the culture period-as in Group 3 - the change was made after the first $24 \mathrm{hr}$. After $48 \mathrm{hr}$ in culture, the embryos were assessed for somite formation and protein content.

Even at very slow rates of flow (Groups 10 and 11 ), 95\% $\mathrm{O}_{2}$ proved harmful to the explants. The yolk sacs expanded only to about 1.5 to $2.0 \mathrm{~mm}$ diameter, no blood circulation was established, and embryonic development was limited to a small knob of tissue in which a few somites could be counted only with some difficulty. However, $95 \% \mathrm{O}_{2}$ gave good results if introduced after $24 \mathrm{hr}$ (Group 9) when the embryos had grown to ten or more somites. The embryos

TABLE 1

DEVELOPMENT OF EMBRYOS EXPLANTED AT PRIMITIVE STREAK TO HEAD-FOLD STAGES AND GROWN IN GIRGULATING SERUM

\begin{tabular}{c|c|c|c|c}
\hline $\begin{array}{c}\text { Group } \\
\text { no. }\end{array}$ & $\begin{array}{c}\text { Oxygen } \\
\text { concentration }\end{array}$ & $\begin{array}{c}\text { Flow rate } \\
(\text { ml/min })\end{array}$ & $\begin{array}{c}\text { Somites } \\
\text { formed }\end{array}$ & $\begin{array}{c}\text { Protein } \\
\text { synthesized }(\mu g)\end{array}$ \\
\hline 1 & $5 \%$ & 1 & 14 & 39 \\
2 & $5 \%$ & 10 & 15 & 42 \\
\hline 3 & $5 \% \rightarrow 20 \%$ & $1 \rightarrow 10$ & 13 & 50 \\
\hline 4 & $20 \%$ & $0 \cdot 2$ & 17 & 75 \\
5 & $20 \%$ & $0 \cdot 8$ & 16 & 66 \\
6 & $20 \%$ & 4 & 22 & 83 \\
7 & $20 \%$ & $1 \rightarrow 10$ & 21 & 90 \\
8 & $20 \%$ & 10 & 19 & 69 \\
\hline 9 & $20 \% \rightarrow 95 \%$ & 1 & 19 & 79 \\
\hline 10 & $95 \%$ & $0 \cdot 3$ & 6 & $<20$ \\
11 & $95 \%$ & 1 & 2 & $<20$ \\
\hline
\end{tabular}

developed well in all the cultures with $20 \% \mathrm{O}_{2}$ (Groups 4 to 8 ) and much better than in those with $5 \% \mathrm{O}_{2}$ (Groups 1 and 2) even when this was replaced by $20 \% \mathrm{O}_{2}$ after the first $24 \mathrm{hr}$ (Group 3). Of the embryos grown in $20 \% \mathrm{O}_{2}$, the best results were obtained in serum flowing at $4 \mathrm{ml} / \mathrm{min}$ (Group 6) and $1 \mathrm{ml} /$ min increased to $10 \mathrm{ml} / \mathrm{min}$ (Group 7), but the differences are too small to be certain from this number of embryos that there is here any indication of optimum rates of flow.

In serum equilibrated with $20 \% \mathrm{O}_{2}$, the yolk sacs expand to 3 to $4 \mathrm{~mm}$ diameter and the better embryos develop a good blood circulation with a heart rate of 130 to 140 beats per min. Those explanted at head-fold stages (conceptus length $>1.5 \mathrm{~mm}$ ) grow much better than younger stages and may develop up to twenty-eight somites.

Comparison was made of embryos grown in circulators with those grown in watch glasses containing $1 \mathrm{ml}$ serum. The explants from $9 \frac{1}{2}$-day pregnant rats sink in serum and their respiration is therefore affected by the depth of the serum in the watch glass. Some of the explants were supported on a strip of coverslip in the watch glass so that the embryo lay just below the surface of the 


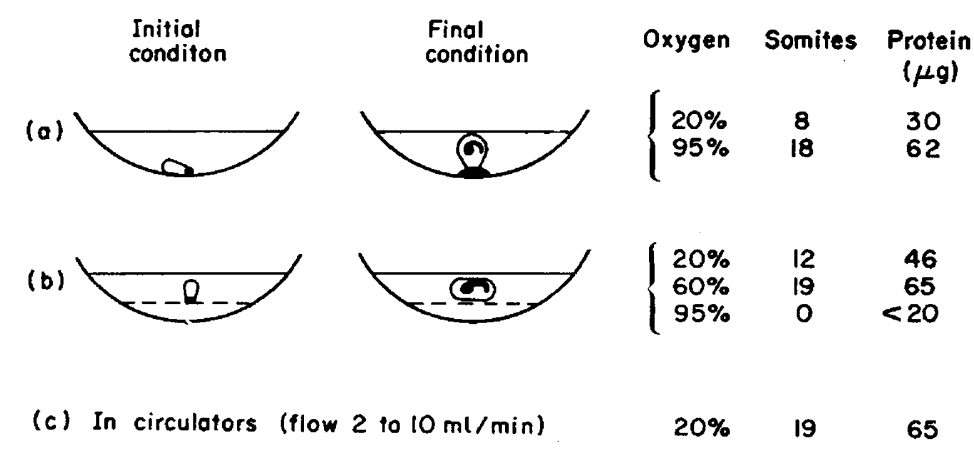

TExT-Fic. 1. Development of embryos explanted at primitive streak to head-fold stages and grown (a) attached to the bottom of a watch glass of serum, (b) supported near the surface of a watch glass of serum, and (c) in circulating serum.

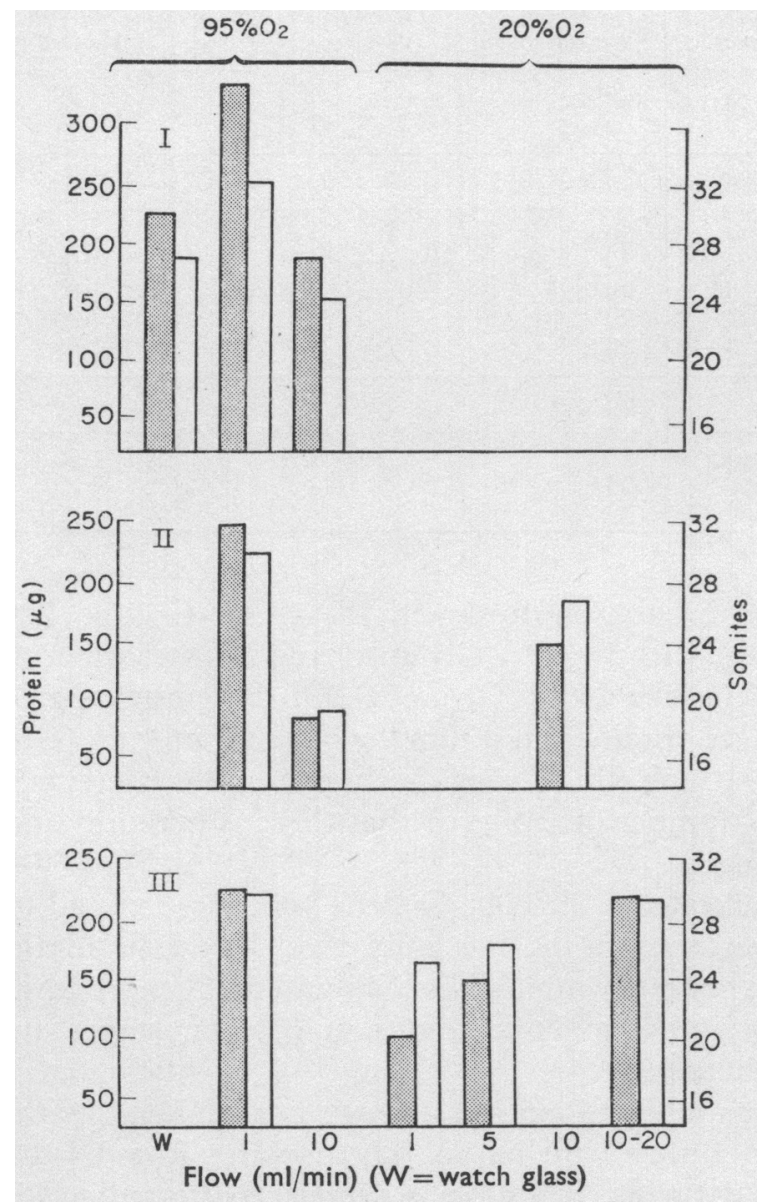

TEXT-FIG. 2. Development as indicated by somites formed (open columns) and growth as indicated by final protein content (stippled columns) of embryos explanted at $10 \frac{1}{2}$ days and grown in circulating serum. 
serum throughout the culture period. Others were placed in the bottom of the watch glass so that initially the embryo lay under about $2 \mathrm{~mm}$ depth of serum but was gradually raised up through it as the yolk sac expanded. Thirty embryos were divided into six groups for different treatments and the results are shown in Text-fig. 1. The best results were obtained from the supported embryos in $60 \% \mathrm{O}_{2}$, the more deeply submerged embryos in $95 \% \mathrm{O}_{2}$ and those in circulating serum equilibrated with $20 \% \mathrm{O}_{2}$; the results from these three groups were very similar.

Embryos explanted at $10 \frac{1}{2}$ days (six to fifteen somites) and $11 \frac{1}{2}$ days (twenty-two to twentyeight somites)

Text-figs. 2 and 3 summarize the results of five experiments in which embryos explanted at $10 \frac{1}{2}$ and $11 \frac{1}{2}$ days were grown under different conditions of oxygenation. Three or four litters were used for each experiment but the embryos of

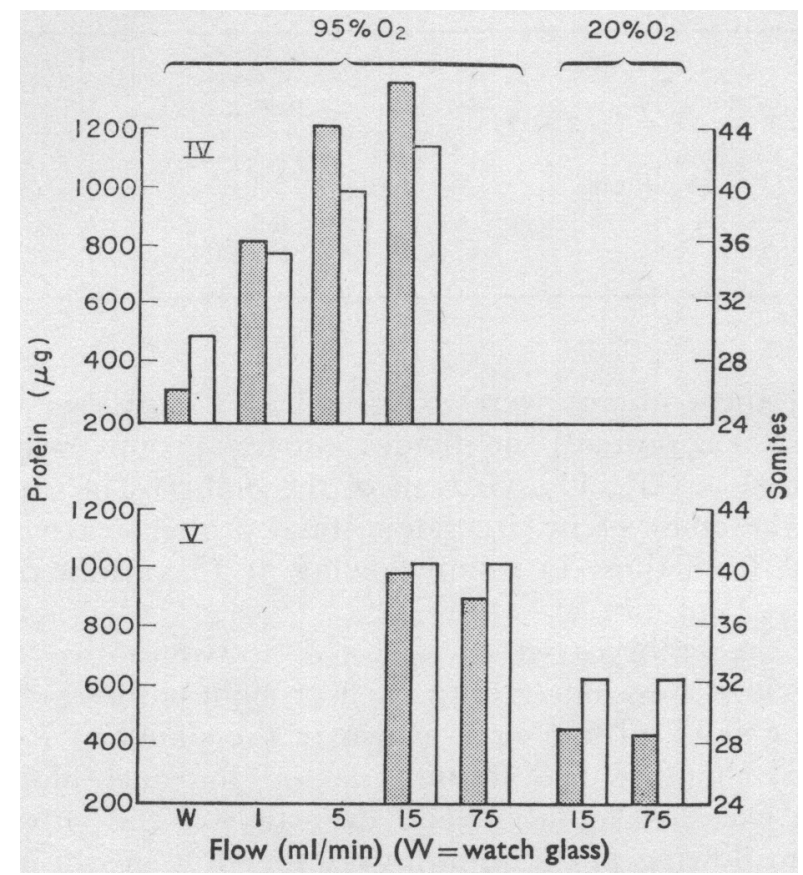

TEXT-FIG. 3. Somites formed (open columns) and final protein content (stippled columns) of embryos explanted at $11 \frac{1}{2}$ days and grown in circulating serum.

each litter were divided among the different treatments so as to eliminate initial differences between litters. Each rectangle in the histograms represents the mean of determinations made on a group of embryos receiving a particular treatment.

In Exp. I, the embryos were explanted at seven to fifteen somites (20 to $60 \mu \mathrm{g}$ protein), and were divided into three groups each of twelve embryos. All were cultured in $95 \% \mathrm{O}_{2}$. Most growth and development was shown by the embryos in serum flowing at $1 \mathrm{ml} / \mathrm{min}$. The final protein content of these was significantly 
greater than that formed either by the embryos in watch glasses $(P<0 \cdot 01)$ or those in serum flowing at $10 \mathrm{ml} / \mathrm{min}(P<0.01)$.

In Exp. II, the embryos were explanted at six to eleven somites, and were divided into three groups each of six embryos. Final protein was significantly greater $(P<0.01)$ in $95 \% \mathrm{O}_{2}$ at $1 \mathrm{ml} / \mathrm{min}$ than in $20 \% \mathrm{O}_{2}$ at $10 \mathrm{ml} / \mathrm{min}$, and it was significantly greater $(P<0.0 \mathrm{I})$ in $20 \% \mathrm{O}_{2}$ at $10 \mathrm{ml} / \mathrm{min}$ than in $95 \% \mathrm{O}_{2}$ at $10 \mathrm{ml} / \mathrm{min}$.

In Exp. III, the embryos were explanted at nine to fourteen somites, and were divided into four groups each of four to six embryos. Final protein was similar in $95 \% \mathrm{O}_{2}$ at $1 \mathrm{ml} / \mathrm{min}$ and in $20 \% \mathrm{O}_{2}$ at 10 to $20 \mathrm{ml} / \mathrm{min}$, but significantly greater in both than in $20 \% \mathrm{O}_{2}$ at $1 \mathrm{ml} / \mathrm{min}(P<0.001)$.

TABLE 2

GROWTH OF YOLK SAG AND EMBRYO UNDER DIFFERENT CONDITIONS OF OXYGENATION

\begin{tabular}{|c|c|c|c|}
\hline Treatment & $\begin{array}{l}\text { No. } \\
\text { of embryos }\end{array}$ & $\begin{array}{l}\text { Yolk sac diameter }(\mathrm{mm}) \\
\text { mean } \pm \text { S.E. }\end{array}$ & $\begin{array}{l}\text { Embryo protein }(\mu g) \\
\quad \text { mean } \pm \text { S.E. }\end{array}$ \\
\hline $\mathrm{A}\left\{\begin{array}{lll}95 \% & \mathrm{O}_{2} & 1 \mathrm{ml} / \mathrm{min} \\
95 \% & \mathrm{O}_{2} & 15 \text { to } 20 \mathrm{ml} / \mathrm{min}\end{array}\right.$ & $\begin{array}{l}8 \\
8\end{array}$ & $\begin{array}{l}6 \cdot 4 \pm 0 \cdot 1 \\
6 \cdot 4 \pm 0.2\end{array}$ & $\begin{array}{r}796 \pm 69 \\
1306 \pm 123\end{array}$ \\
\hline B $\left\{\begin{array}{lll}20 \% & \mathrm{O}_{2} \\
95 \% & \mathrm{O}_{2}\end{array}\right.$ & $\begin{array}{l}12 \\
12\end{array}$ & $\begin{array}{l}6 \cdot 9 \pm 0 \cdot 2 \\
6 \cdot 4 \pm 0 \cdot 2\end{array}$ & $\begin{array}{r}400 \pm 40 \\
1010 \pm 102\end{array}$ \\
\hline
\end{tabular}

In Exp. IV, the embryos were explanted at twenty-two to twenty-eight somites ( 150 to $300 \mu \mathrm{g}$ protein) and divided into four groups each of six embryos. All were cultured in $95 \% \mathrm{O}_{2}$. Growth of the embryos in watch glasses was negligible. Of the embryos in circulators, final protein was very significantly greater $(P<0.001)$ in those in serum flowing at $15 \mathrm{ml} / \mathrm{min}$ than in those in serum flowing at $1 \mathrm{ml} / \mathrm{min}$.

In Exp. V, the embryos were explanted at twenty-two to twenty-eight somites and divided into four groups each of eight embryos. The two groups in serum flowing at $15 \mathrm{ml} / \mathrm{min}$ were grown in the standard $7 \times 7-\mathrm{mm}$ embryo chambers. These chambers proved unsatisfactory for much higher rates of flow because of the excessive agitation and distortion of the yolk sacs. The two groups in serum flowing at $75 \mathrm{ml} / \mathrm{min}$ were therefore grown in slightly larger embryo chambers as shown in Text-fig. 4. These were cylindrical and $10 \mathrm{~mm}$ in diameter, and the embryos were supported in the chamber on rayon raised from the floor of the chamber on a wire frame, so that the serum flowed under as well as over and around the explants. However, the histogram shows that both groups of embryos in $95 \% \mathrm{O}_{2}$ attained similar stages of growth and development and the final protein was significantly greater $(P<0 \cdot 001)$ than in either group in $20 \% \mathrm{O}_{2}$.

\section{Heart and blood circulation}

The embryonic and yolk sac blood circulations developed well in nearly all the explanted embryos, except those cultured under the most harmful con- 
ditions of oxygen lack or excess. In the $10 \frac{1}{2}$ - and $11 \frac{1}{2}$-day embryos the circulation was maintained for $30 \mathrm{hr}$ or more but had usually failed by $40 \mathrm{hr}$. In the $9 \frac{1}{2}$-day embryos, a good circulation was often present $40 \mathrm{hr}$ after explantation but it rarely persisted beyond $48 \mathrm{hr}$.

The heart rate of embryos explanted at $9 \frac{1}{2}$ and $10 \frac{1}{2}$ days was usually 80 to 90 beats per min at the time of onset of the blood circulation (about the ten-somite stage) rising to 120 to 150 as development progressed. Heart rates of embryos explanted at $11 \frac{1}{2}$ days usually attained 140 to 170 beats per min, occasionally increasing to 190 .

When growth was hindered by an excess or shortage of $\mathrm{O}_{2}$, the blood circulation and heart rate were also affected. For example, $10 \frac{1}{2}$-day embryos which

(a)

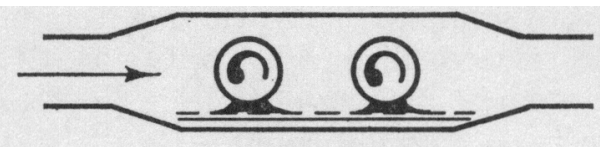

(b)

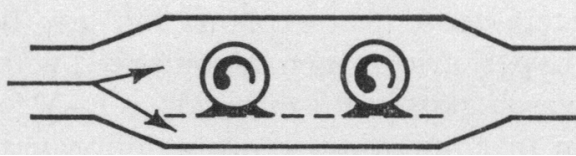

TEXT-FIG. 4. Two types of embryo chamber used in circulators.

were over-oxygenated by growing them in rapidly flowing serum equilibrated with $95 \% \mathrm{O}_{2}$ rarely developed a heart rate of more than 100 beats per min. On the other hand, the $11 \frac{1}{2}$-day embryos growing in $20 \% \mathrm{O}_{2}$ (Text-fig. 3 ) had no yolk sac blood circulation after $18 \mathrm{hr}$ and an average heart rate of only 65 beats per min, compared with the well developed circulation and heart rate of 150 to 170 shown by those in $95 \% \mathrm{O}_{2}$.

In vivo, the allantoic circulation is established at about the twenty-somite stage and the embryos explanted after this stage maintained the allantoic circulation in culture. Younger embryos failed to develop an allantoic circulation and often formed a large abnormal vessel which bypassed the allantoic vessels, as described previously (New, 1967).

Growth of the yolk sac

Culture conditions that favoured growth of the younger embryos also favoured growth of the yolk sac. In the $11 \frac{1}{2}$-day explants, however, embryo and yolk sac responded very differently to variations in $\mathrm{O}_{2}$ supply. This is shown in Table 2. Each part of the table compares the growth obtained under two levels of oxygenation, and litters were divided equally between the two treatments to ensure that the embryos were comparable. All the embryos were at twenty-two- to twenty-eight-somite stages when explanted.

Table 2A compares growth in serum circulated at $1 \mathrm{ml} / \mathrm{min}$ with that in serum circulated at 15 to $20 \mathrm{ml} / \mathrm{min}$. All the serum was equilibrated with $95 \%$ $\mathrm{O}_{2}$. The results show that the faster flowing serum supported much more 
growth of the embryos than the slower, but there was no difference in the size attained by the yolk sacs.

Table 2B compares growth in circulated ( 15 to $75 \mathrm{ml} / \mathrm{min}$ ) serum equilibrated with $20 \% \mathrm{O}_{2}$ with that in serum equilibrated with $95 \% \mathrm{O}_{2}$. Again the embryos, but not the yolk sacs, grew much more under the conditions of higher oxygenation. The average yolk sac diameter was in fact slightly, but significantly $(P<0.05)$, greater in the $20 \% \mathrm{O}_{2}$ than in the $95 \% \mathrm{O}_{2}$.

\section{Hyperbaric oxygen}

A few trials were made with embryos cultured in hyperbaric oxygen. Twentyfour $11 \frac{1}{2}$-day embryos were placed in serum in small cylindrical dishes and either allowed to float in the serum or attached to rayon on the bottom of the dish and covered with serum to depths varying from 0 to $5 \mathrm{~mm}$. Gas chambers containing the cultures were filled with $95 \% \mathrm{O}_{2}-5 \% \mathrm{CO}_{2}$ and then extra oxygen was added to give a gauge reading of $15 \mathrm{lb} / \mathrm{in}^{2}{ }^{2}$ ( = total pressure of 2 atmospheres) or $30 \mathrm{lb} /$ in. $^{2}$ ( $=3$ atmospheres).

The results showed that appreciable growth (up to thirty-eight somites and with twice the protein content at explantation) can be obtained from $11 \frac{1}{2}$-day embryos grown in hyperbaric oxygen as compared with the negligible growth of these embryos in watch glass cultures in $95 \% \mathrm{O}_{2}-5 \% \mathrm{CO}_{2}$ at normal pressure. But controls grown in circulating serum equilibrated with $95 \% \mathrm{O}_{2}-5 \% \mathrm{CO}_{2}$ developed further, up to forty-five somites and with three to four times the protein content at explantation.

Five embryos explanted at $12 \frac{1}{2}$ days (thirty-six to forty somites) and cultured under the same conditions in oxygen at 2 atmospheres showed no growth or development.

\section{DISCUSSION}

The work that has been described leads to the following main conclusions:

(1) Embryos explanted at head-fold stage grow to twenty to twenty-five somites in watch glass cultures in 60 to $95 \% \mathrm{O}_{2}$ or in circulating serum equilibrated with $20 \% \mathrm{O}_{2}$. Poor results are obtained in watch glass cultures in $20 \%$ $\mathrm{O}_{2}$, or in circulating serum equilibrated with $5 \%$ or $95 \% \mathrm{O}_{2}$.

(2) Embryos explanted at about the ten-somite stage grow to twenty-five to thirty somites in watch glass cultures in 60 to $95 \% \mathrm{O}_{2}$, or to thirty to thirty-five somites in circulating serum equilibrated with $20 \%$ or $95 \% \mathrm{O}_{2}$. The rate of flow of serum in the circulators must be rapid with $20 \% \mathrm{O}_{2}$, slow with $95 \% \mathrm{O}_{2}$.

(3) Embryos explanted at about the twenty-five-somite stage grow to forty to forty-five somites in rapidly circulated serum equilibrated with $95 \% \mathrm{O}_{2}$. Little growth is obtained in watch glass cultures or in circulating serum equilibrated with $20 \% \mathrm{O}_{2}$. Hyperbaric oxygen improves the results in static serum but the amount of growth is much less than in circulating serum.

(4) The heart and blood circulation function best in the same oxygen conditions that promote most embryonic growth.

(5) Yolk sac expansion continues at oxygen concentrations below those necessary for embryonic growth. 
It is clear that rat embryos can easily be killed by too little or too much $\mathrm{O}_{2}$ and that the optimum concentration for growth in culture varies widely with the stage of development of the embryos. It is well known that major abnormalities of development in vivo can result from abnormal oxygen conditions (Zarrow, 1961), and the simplest explanation for the apparently varied oxygen requirements in culture may be that the embryo requires in its tissues an oxygen pressure similar to that provided by blood in equilibrium with air. Thus, in circulating serum, the younger embryos grow best in $20 \% \mathrm{O}_{2}$ but, in static serum, require higher concentrations of $\mathrm{O}_{2}$ in the gas chamber to allow for the gradient established between gas phase and embryo. For embryos of more than twenty somites, there is a shortage of respiratory surfaces in culture because they lack the allantoic circulation present in vivo. To compensate for this, the $\mathrm{O}_{2}$ in the serum surrounding the yolk sac must be raised (to $95 \%$ for maximum results) so that sufficient will be carried by the yolk sac blood circulation, and diffuse through the yolk sac and amniotic fluids, to maintain the optimal level in the embryo.

The yolk sac itself, which is in direct contact with the nutrient serum, expands normally in $20 \% \mathrm{O}_{2}$ at all stages from primitive streak to forty-five somites. It is also surprisingly tolerant, in the later stages, of serum equilibrated with $95 \% \mathrm{O}_{2}$ and it is this tolerance that makes possible the growth of embryos beyond the thirty-somite stage.

No embryo develops for long unless the heart and blood circulation are functioning well. It seems likely that the failure of the largest embryos to develop beyond forty-five somites may be caused primarily by slowing of the heart beat resulting from $\mathrm{O}_{2}$ shortage. Shepard, Tanimura, Robkin \& Bass (personal communication) have observed that, if the gas phase of cultures containing twenty- to thirty-somite embryos in circulating medium is changed from $95 \% \mathrm{O}_{2}$ to $20 \% \mathrm{O}_{2}$, the heart rate falls to low values within a few minutes.

The problem of supplying sufficient $\mathrm{O}_{2}$ in culture to organs and tissues of more than a millimetre or so in thickness has been studied by several workers in recent years (e.g. Trowell, 1961; Moscona, Trowell \& Willmer, 1965). Increasing the proportion and pressure of the $\mathrm{O}_{2}$ in the gas phase has been recognized as a useful method, but the value of flowing media has been more uncertain. Results have often been poor, and it has been suggested that flowing media may leach out essential metabolites. Our results with rat embryos have emphasized both the heavy demand for $\mathrm{O}_{2}$ made by the larger embryos and the importance of flowing medium as a means of supplying it. If any harmful leaching occurred in our flow cultures, its effects must have been small compared with the advantages gained from the increased $\mathrm{O}_{2}$ supply.

As yet, no post-implantation rodent embryos of stages younger than primitive streak or older than forty-five somites have been successfully grown in culture. Some promising results with rabbit embryos of implantation stages have been obtained by Glenister (1966) and Daniel (1970). Krishnan \& Daniel (1967) have shown that in the rabbit a specific uterine protein, blastokinin, acts as an important stimulus to the earlier stages of embryonic development, and it seems likely that substances with a similar function will be identified in rats, mice and other rodents. For the larger embryos, the limiting factor appears to be rate of 
$\mathrm{O}_{2}$ supply. The use of hyperbaric oxygen and of flowing medium have each extended embryonic development well beyond the more conventional culture systems but the limits of these two methods alone seem now to have been reached. There remains the possibility of employing them in combination using flowing medium inside a pressure chamber and this is now being investigated.

\section{REFERENCES}

BERRY, C. L. (1968) Comparison of in vivo and in vitro growth of the rat foetus. Nature, Lond. $219,92$.

DANiEL, J. C. (1970) Culture of the rabbit blastocyst across the implantation period. In: Methods in Mammalian Embryology. Ed. J. C. Daniel. Freeman, San Francisco and London.

Givelber, H. M. \& Di Paolo, J. A. (1968) Growth of explanted 8-day hamster embryos in circulating medium. Nature, Lond. 220, 1131.

Glenister, T. W. (1966) Organ culture and its combination with electron microscopy in the study of nidation processes. Excerpta med. Int. Congr. Series, No. 133, 385.

Krishnan, R. S. \& Daniel, J. C. (1967) "Blastokinin": inducer and regulator of blastocyst development in the rabbit uterus. Science, $\mathcal{N}, Y .158,490$.

Lowry, O. H., Rosebrough, N. J., Farr, A. L. \& Randall, R. J. (1951) Protein measurement with the Folin phenol reagent. 7. biol. Chem. 193, 265.

Moscona, A., Trowelt, O. A. \& Willmer, E. N. (1965) Chapter on Methods in Cells and tissues in culture, Vol. 1, p. 71 and 82. Ed. E. N. Willmer. Academic Press, London and New York.

New, D. A. T. (1966a) The culture of vertebrate embryos. Logos Press, London.

New, D. A. T. (1966b) Development of rat embryos cultured in blood sera. 7. Reprod. Fert. $12,509$.

NEw, D. A. T. (1967) Development of explanted rat embryos in circulating medium. F. Embryol. exp. Morph. 17, 513 .

New, D. A. T. (1970) Methods for the culture of post-implantation rodents. In: Methods in Mammalian Embryology. Ed. J. C. Daniel. Freeman, San Francisco and London.

Trowell, O. A. (1961) Problems in the maintenance of mature organs in vitro. In: La Culture Organotypique. Colloques int. Cent. natn. Rech. scient. 101.

Turbow, M. M. (1966) Trypan blue induced teratogenesis of rat embryos cultivated in vitro. F. Embryol. exp. Morph. 15, 387.

Zarrow, M. X. (1961) Gestation. In: Sex and Internal Secretions. Ed. W. C. Young. Williams \& Wilkins, Baltimore. 